\title{
EVALUASI MODEL MEDIA AUDIO DAILY ENGLISH CONVERSATION PADA SISWA SMP DI YOGYAKARTA
}

\section{Evaluation of Daily English Conversation Audio Media Model for Junior High School Students in Yogyakarta}

\author{
Suparti \\ Balai \\ Pengembangan Media Radio Pendidikan dan Kebudayaan (BPMRK) \\ Kementerian Pendidikan dan Kebudayaan \\ Jl. Surowajan Baru 367 Banguntapan Yogyakarta, Indonesia \\ suparti@kemdikbud.go.id
}

\footnotetext{
Diterima:

15 Juli 2017, direvisi:

28 Juli 2017, disetujui: 10 Agustus 2017.
}

\begin{abstract}
The developed DEC learning model for junior high school students has never been evaluated its feasibility. Therefore, this research aims at evaluating the feasibility degree of Daily English Conversation (DEC) model in respect to its content quality, media, excellences, as well as weaknesses. Data collecting is done through observation, questionnaire, and interviews. The research is carried out from August through September 2016 with the population of Junior High School students at SSC-I Course in Yogyakarta. Sample is taken by random sampling technique involving 36 respondents. Beside students, this research also involves two educators. The result shows that: (1) the content quality consisting of listening and speaking skills, material scope-presentation-as well as difficulty degree, and language usage shows effectiveness value of 74,7\%; and (2) the media consisting of speaking fluency, voice clarity and attractiveness, program tune, sound effect usage, music illustration, duration, and utilization easiness shows the effectiveness value of $70,1 \%$. However, there are some points suggested to be improved for the next model development.
\end{abstract}

$\begin{array}{ll}\text { Keywords: } & \text { evaluation, audio media, Daily English } \\ \text { Conversation }\end{array}$

ABSTRAK: Model bahan belajar Daily English Conversation (DEC) yang telah dikembangkan untuk peserta didik SMP belum pernah dievaluasi kelayakannya. Oleh karena itu penelitian ini bertujuan menilai tingkat kelayakan model $D E C$ ditinjau dari aspek kualitas isi/materi, kemediaan, dan kelebihan serta kekurangan. Metode pengumpulan data dalam penelitian ini adalah pengamatan, kuesioner, dan wawancara. Penelitian dilakukan pada bulan Agustus-September 2016 dengan populasi siswa SMP di lembaga bimbingan belajar SSC-I Yogyakarta. Sampel diambil dengan teknik simple random sampling yang melibatkan 36 responden siswa. Selain siswa, dilibatkan juga dua praktisi pendidik/pengajar. Hasil evaluasi menunjukkan bahwa: (1) aspek isi/materi pembelajaran yang meliputi pengembangan kemampuan menyimak dan berbicara, cakupan materi, penyajian materi, tingkat kesulitan materi, dan 
penggunaan bahasa menunjukkan tingkat efektivitas sebesar $74,7 \%$; dan (2) aspek media yang meliputi kecepatan ucapan, kejelasan dan kemenarikan suara, tune program, penggunaan efek suara, ilustrasi musik, durasi, dan kemudahan penggunaan efektivitas model media audio DEC menunjukkan persentase sebesar 70,1\%. Namun disarankan agar beberapa hal yang terkait pengembangan materi dan pengemasan program diperbaiki pada pengembangan model berikutnya.

Kata Kunci: evaluasi, media audio, Daily English Conversation

\section{PENDAHULUAN}

Balai Pengembangan Media Radio Pendidikan dan Kebudayaan (BPMRPK) merupakan sebuah institusi yang bergerak dalam bidang pengembangan model dan format sajian media audio radio untuk pendidikan dan kebudayaan. Dalam rangka mengemban tugas tersebut, setiap tahunnya BPMRPK selalu mengembangkan berbagai model dan format sajian media audio/radio untuk kepentingan dunia pendidikan di Indonesia. Salah satu pengembangan yang dilakukan BPMRPK pada tahun 2016 adalah pengembangan media audio Daily English Conversation (DEC).

Pembuatan bahan belajar DEC dilatarbelakangi oleh kenyataan bahwa kemampuan berbahasa Inggris orang Indonesia, khususnya para pelajar bahkan mahasiswa masih sangat rendah. Hal ini diperburuk dengan kenyataan bahwa guru bahasa Inggris cenderung mengabaikan pembelajaran listening dibandingkan ketiga keterampilan berbahasa lainnya (speaking, reading, dan writing). Akibatnya pembelajaran listening menjadi kurang berkembang (Adnan, 2012: 1). Hal itu sejalan dengan penelitian yang menyatakan bahwa kemampuan lulusan sekolah setingkat SMA masih belum memadai. Kenyataan itu semakin tampak ketika mereka diminta mengungkapkan gagasan mereka dalam bahasa Inggris, banyak yang mengalami kesulitan (Nurkamto, 2003: 288). Pada intinya, meskipun sudah bertahun-tahun belajar bahasa Inggris, kemampuan berbicara dalam bahasa Inggris siswa atau mahasiswa di Indonesia pada umumnya masih rendah.

Hasil survei yang dilakukan oleh sebuah perusahaan pendidikan skala internasional bernama English First (EF) menunjukkan bahwa kemampuan kecakapan berbahasa Inggris orang dewasa di Indonesia berada pada urutan ke-32 dari 72 negara yang disurvei (Valentina, 2016). Selain itu, berdasarkan survei dari hasil tes awal yang dilakukan calon siswa EF, 46,5\% dari mereka memiliki kemampuan berbicara dua level lebih rendah di bawah kemampuan membaca dan menyimak. Selain itu, kemampuan berbicara calon siswa tersebut juga rendah, padahal kemampuan berkomunikasi dalam berbahasa Inggris terutama dalam skala nasional dan internasional sangat diperlukan (Citra, 2016).

Bahasa Inggris merupakan bahasa asing utama yang penting untuk tujuan mengakses informasi, menyerap dan mengembangkan ilmu pengetahuan dan teknologi, mengenalkan seni budaya dan membina hubungan dengan bangsa-bangsa lain. Bahasa Inggris merupakan bahasa internasional yang memainkan peran sangat penting dalam komunikasi dunia. Selain itu, bahasa Inggris juga digunakan untuk mengontrol teknologi yang semakin berkembang dan menuntut pembelajar untuk belajar lebih banyak lagi (Astuti, Sunardi, Nurkamto, 2014: 394). Hal ini menjadi ironi karena keterampilan berbahasa Inggris, khususnya dalam kehidupan sehari-hari, sangat diperlukan apalagi dalam rangka menyambut adanya program Masyarakat Ekonomi Asia (MEA).

Beberapa kendala yang dihadapi pelajar Indonesia dalam berbicara bahasa Inggris antara lain menyangkut pengucapan atau pronunciation, kelancaran berbicara atau fluency, tata bahasa atau grammar, dan kosa kata atau vocabulary. Selain itu, permasalahan lain yang dihadapi adalah kurangnya kepercayaan diri, malu untuk 
berbicara dalam bahasa Inggris, takut berbuat kesalahan, dan tidak tahu apa yang harus dikatakan (Sayuri, 2016: 47). Rendahnya kemampuan berbicara ini beriringan dengan kemampuan menyimak di mana permasalahan yang dihadapi pembelajar dalam menyimak teks bahasa Inggris relatif sama dengan kendala yang dihadapi dalam berbicara dalam bahasa Inggris.

Ada beberapa kendala yang dialami pembelajar dalam kaitannya dengan kemampuan menyimak bahasa asing, antara lain: tidak dapat memahami pengucapan (pronunciation), keterbatasan kosa kata pembelajar, kesulitan/kegagalan dalam berkonsentrasi, dan keterbatasan mengakses authentic materials atau materi otentik dalam pembelajaran (Alzuhdy, 2014: 2).

Sebagai sebuah institusi yang berada di bawah Kementerian Pendidikan dan Kebudayaan (Kemendikbud), BPMRPK berusaha menjawab tantangan tersebut melalui pengembangan model media audio Daily English Conversation (DEC). DEC merupakan media audio yang berisi model teks percakapan dalam bahasa Inggris yang diikuti penjelasan narator mengenai ungkapan-ungkapan yang digunakan; menjelaskan bagaimana percakapan tersebut digunakan dalam konteks tertentu serta memberikan contoh pengucapan atau pronounciation yang benar dalam Bahasa Inggris. Dalam pemanfaatannya, DEC dapat dimanfaatkan secara offline dalam pembelajaran di kelas, pembelajaran mandiri ataupun disiarkan melalui stasiun radio. Media audio ini diharapkan dapat digunakan untuk meningkatkan kemampuan listening (menyimak) dan speaking (berbicara).

Menyimak sendiri merupakan sebuah proses dalam mendengarkan suara atau bunyi yang memanfaatkan indera pendengaran, yang dilakukan dengan penuh perhatian, apresiasi, dan interpretasi untuk menangkap pesan yang diperdengarkan dan memperoleh informasi serta memahami isi pesan yang disampaikan lewat suara/bunyi yang diperdengarkan (Risa, 2015: 7-8). Keterampilan menyimak menyangkut kemampuan dalam menafsirkan makna dari bunyi-bunyi bahasa yang berupa kata, kalimat, tekanan, dan nada yang disampaikan pembicara dalam suatu konteks komunikasi tertentu. Sementara itu, seseorang dikatakan memiliki keterampilan berbicara apabila yang bersangkutan terampil memilih bunyi-bunyi bahasa dan memformulasikannya secara tepat untuk menyampaikan pikiran, perasaan, gagasan, fakta, perbuatan dalam suatu konteks komunikasi tertentu (Mulyati, 2015: 6). Jadi keterampilan menyimak merupakan materi penting dalam pembelajaran bahasa Inggris karena untuk bisa merespons suatu ucapan, seseorang harus memiliki kemampuan atau keterampilan menyimak yang baik.

Pada kenyataannya, sebagaimana diungkapkan oleh Sekretaris Jenderal Kemendikbud bahwa keterampilan berbahasa Inggris lulusan SMP dan SMA, terutama keterampilan berbicara dan menyimak relatif masih rendah dan kalah dibandingkan negara-negara lain, misalnya Filippina. Pustekkom, khususnya BPMRPK, punya andil untuk meningkatkan perannya, dengan rutin melakukan evaluasi, bersinergi dengan semua direktorat yang ada di Kemendikbud, khususnya dalam hal pengembangan media audio pendidikan, salah satunya media audio pendidikan bahasa Inggris (Susanti, 2017). Sejalan dengan himbauan Sekjen Kemendikbud tersebut, media audio DEC merupakan salah satu media yang diharapkan dapat memberikan peran dalam menyediakan sumber belajar bahasa Inggris bagi pembelajar, khususnya untuk meningkatkan keterampilan menyimak dan berbicara.

DEC pada dasarnya dikembangkan dengan mengadopsi pengembangan model ADDIE yang terdiri dari 5 tahapan yaitu: Analyze, Design, Develop, Implement, Evaluate yang merupakan terjemahan dari Analisis, Desain, Pengembangan, Pemanfaatan, dan Evaluasi (Forest, 2014: 1). Secara umum, tujuan pengembangan model DEC adalah membantu pembelajar bahasa Inggris mengenal berbagai percakapan Bahasa Inggris yang lazim digunakan dalam kehidupan sehari-hari sebagai upaya untuk meningkatkan kemampuan menyimak dan berbicara. 
Dalam konteks ini, tahap analisis dilakukan dengan menentukan tujuan dan target sasaran model bahan siar yang akan dikembangkan. Pada tahap desain, disusunlah blue print atau cetak biru mengenai model bahan siar yang akan dikembangkan, terutama menyangkut pemetaan materi dan format sajian program. Pada tahap pengembangan, proses produksi dimulai, baik menyangkut proses penulisan maupun produksi program. Setelah proses produksi selesai, masuk pada tahap implementasi atau pemanfaatan dan selanjutnya tahap terakhir adalah evaluasi.

Salah satu manfaat dari evaluasi adalah mengumpulkan data dan informasi yang akan digunakan untuk menentukan kebijakan berikutnya dan menentukan tolak ukur mengenai efektivitas dan efisiensi dari model media audio yang dikembangkan (Suparti, 2016: 86). Umumnya, evaluasi program digunakan untuk mengukur kemajuan dalam pencapaian tujuan, meningkatkan implementasi suatu program, menyediakan informasi yang memadai bagi pengambil kebijakan, dan menjamin keefektifannya (Wang, 2010: 130). Dengan demikian, evaluasi memegang peranan penting dalam penentuan suatu kebijakan. Dengan evaluasi, efektivitas dan efisiensi suatu program atau sebuah model media pembelajaran yang telah dan akan dilakukan dapat ditingkatkan. Evaluasi bermanfaat untuk perbaikan mutu sebuah program atau model media pembelajaran, termasuk media pembelajaran berbasis audio. Pada umumnya evaluasi merupakan tahapan akhir dalam pengembangan sebuah model media pembelajaran, namun sesungguhnya evaluasi juga dilakukan pada setiap langkah pengembangan.

Evaluasi pengembangan media juga diartikan sebagai upaya dalam rangka pengumpulan, pengolahan, serta interpretasi data dan informasi terhadap proses dan hasil pengembangan dan pemanfaatan program media, yang selanjutnya digunakan untuk menentukan alternatif yang tepat dalam mengambil keputusan (Rahadi, 2015). Dengan demikiani, evaluasi merupakan sebuah proses untuk mendapatkan data dan informasi apakah proses pengembangan media telah sesuai tujuan, apakah produk yang dihasilkan sesuai dengan rancangan, apakah bisa diimplemantasikan sesuai desain model dan memberikan pengaruh positif sesuai dengan tujuan pengembangan.

Berdasarkan prosesnya, evaluasi pengembangan media dapat dibedakan menjadi evaluasi formatif dan sumatif. Evaluasi formatif merupakan evaluasi yang berfokus pada kinerja yang lebih baik, baik itu menyangkut kebijakan maupun program, sementara evaluasi sumatif lebih fokus pada hasil atau akibat dan ditujukan untuk memberikan informasi tentang kegunaan sebuah program (Rahadi, 2015).

Pendapat lain mengemukakan bahwa evaluasi formatif diarahkan pada evaluasi proses untuk menyempurnakan suatu proses sementara evaluasi sumatif diarahkan untuk mengevaluasi hasil apakah program cukup efektif dan efisien atau tidak untuk menentukan keberlanjutan program, apakah akan diteruskan atau dihentikan (Sukmadinata, 2005: 122). Jadi evaluasi formatif dimaksudkan untuk mengumpulkan data tentang efektivitas dan efisiensi media untuk mencapai tujuan yang ditetapkan dengan maksud memperbaiki media yang dikembangkan agar efektif dan efisien. Sementara dalam evaluasi sumatif, proses pengumpulan data dimaksudkan untuk menentukan apakah media yang telah diperbaiki tersebut benar-benar efektif atau tidak.

Ada beberapa penelitian yang dilakukan menyangkut evaluasi media pembelajaran. Salah satunya adalah penelitian evaluatif dalam pengembangan model pembelajaran bahasa Inggris yang mengintegrasikan antara buku siswa, buku guru, dan materi rekaman berbasis audio. Hasil penelitian ini memberikan beberapa rekomendasi terkait evaluasi produk yang dihasilkan. Evaluasi tersebut melibatkan ahli bahasa, ahli media, guru, dan siswa.

Menurut masukan dari ahli bahasa, media yang dikembangkan perlu lebih variatif dalam menyediakan jenis-jenis teks dan lebih disesuaikan dengan konteks dan situasi di mana teks tersebut digunakan dan 
memperhatikan siapa yang terlibat di dalamnya. Sementara itu, saran dari ahli media mengungkapkan bahwa perlu ada sinkronisasi antara media audio dengan bahan penyerta yang berupa buku guru dan buku siswa; sedangkan masukan dari guru menyatakan bahwa 'pauses' atau jeda dalam merespons perintah/pertanyaan dari media audio perlu disesuaikan dengan kebutuhan, penggunaan kosakata hendaknya lebih dekat dengan siswa, dan penggunaan musik sebaiknya dibuat lebih menarik. Sementara itu, dari sisi siswa, mereka cenderung masih enggan untuk merespons perintah-perintah dalam media audio dan masih memerlukan dukungan dari guru untuk meresponnya (Adi, 2016:5-6).

Penelitian relevan lain yang pernah dilakukan terhadap evaluasi kualitas bahan ajar Listening adalah yang berupa media rekam pembelajaran listening yang disertai dengan modul pembelajaran pada pembelajaran jarak jauh. Evaluasi ini melibatkan ahli materi, ahli pengembang instruksional, dan ahli produksi media dan kelompok pengguna. Secara umum hasil penelitian merekomendasikan bahwa dari sisi kualitas audio maupun modul cetak secara umum sudah baik, namun kodifikasi diperlukan untuk mempermudah penggunaan, serta tingkat kecepatan pengucapan penutur asli (native speaker) dalam menyampaikan materi pembelajaran listening perlu dikurangi (Ardiasih dan Juhana, 2013: 28-32).

Penelitian evaluatif yang dilakukan penulis merupakan bagian dari penelitian dalam rangkaian pengembangan model media audio DEC. Penelitian ini diperlukan karena ketersediaan bahan ajar yang berkualitas sangat diperlukan dalam membantu pembelajar untuk meningkatkan kemampuan bahasa Inggris mereka, terutama keterampilan menyimak dan berbicara. Untuk mengetahui apakah bahan ajar yang dikembangkan tersebut telah sesuai dengan tujuan pengembangan program, sudah layak, efektif, efisien, serta menarik bagi calon pengguna, perlu dilakukan evaluasi sehingga menghasilkan rekomendasi yang bermanfaat bagi perbaikan dan pengembangan media audio bahasa Inggris yang dikembangkan. Dengan demikian, penelitian evaluasi ini bertujuan untuk mengetahui tingkat kelayakan atau efektivitas media audio DEC, apakah telah memenuhi standar kualitas, baik dari sisi materi maupun media sehingga layak dimanfaatkan sebagai salah satu bahan ajar bahasa Inggris yang mendukung pembelajaran menyimak dan berbicara.

Dari sisi materi, hal yang dievaluasi meliputi kelayakan DEC dalam mendukung kemampuan menyimak dan berbicara, cakupan materi, penyajian materi, tingkat kesulitan materi, dan penggunaan bahasa. Sementara itu, dari sisi media, hal yang dievaluasi meliputi tempo/kecepatan ucapan, kejelasan suara, kemenarikan suara, kemenarikan tune program, penggunaan efek suara, ilustrasi musik, ketepatan durasi, dan kemudahan penggunaan.

Bagi lembaga, penelitian evaluasi ini bermanfaat dalam perbaikan model media audio bahasa Inggris dan bermanfaat pula untuk menentukan kebijakan dalam pengembangan model media audio bahasa Inggris berikutnya: apakah model ini akan dilanjutkan, dilanjutkan dengan perbaikan, atau dihentikan sama sekali karena dianggap tidak layak.

Bagi calon pengguna, rekomendasi hasil penelitian evaluasi ini bermanfaat dalam memberikan informasi apakah model media audio yang dimaksud telah memenuhi kelayakan untuk digunakan sebagai salah satu sumber belajar bahasa Inggris yang menitikberatkan pada aspek pembelajaran menyimak dan berbicara.

\section{METODA}

Penelitian ini merupakan penelitian evaluatif yang menekankan pada evaluasi proses dengan pendekatan evaluasi sumatif yaitu evaluasi yang dilakukan pada akhir program. Penelitian ini dilaksanakan bulan Agustus-September 2016 dengan mengambil populasi siswa-siswa SMP yang mengikuti bimbingan belajar di lembaga SSC-I Yogyakarta. Sampel diambil dengan teknik simple random sampling.

Dalam penelitian ini, sampel yang diambil 
berjumlah 36 responden. Selain itu, penelitian ini juga melibatkan dua orang praktisi pendidikan sebagai pengajar. Sampel yang diambil tersebut sekaligus menjadi subyek penelitian, sementara yang menjadi obyek penelitian adalah model media audio DEC dengan judul Complimenting dan Inviting Someone. Instrumen yang digunakan dalam penelitian ini adalah kuesioner, observasi, dan wawancara; sedangkan teknik analisis data yang digunakan adalah analisis data kuantitatif dan deskriptif kualitatif. Teknik kuantitatif digunakan untuk menganalisis hasil kuesioner ditinjau dari sisi materi dan kemediaan dengan menggunakan persentase sedangkan teknik deskriptif kualitatif digunakan untuk menganalisis hasil observasi dan wawancara dengan praktisi pendidikan, ahli bahasa, dan siswa. Teknik pengumpulan data melalui lembar pengamatan, kuesioner, dan panduan wawancara dilakukan dengan tujuan mendapatkan jawaban yang lebih valid terkait kuesioner yang telah diberikan.

Sebelum evaluasi model media audio DEC dilakukan, kesiapan praktisi pendidikan/ pengajar dilakukan. Mereka diberikan pengarahan bagaimana media audio tersebut dimanfaatkan dalam pembelajaran di kelas. Dari hasil pengamatan, pada awalnya kepada siswa diperdengarkan media audio tersebut tanpa intervensi apa pun. Selanjutnya siswa diminta untuk menceritakan isi percakapan dalam media audio tersebut. Setelah itu, siswa diberikan intervensi dengan bimbingan pengajar untuk memanfaatkan media audio tersebut dalam pembelajaran dan selanjutnya diminta untuk menceritakan kembali isi percakapan dan mempraktikannya. Pada tahap berikutnya siswa diberikan kuesioner untuk mengukur keefektifan model media audio DEC dalam mendukung pembelajaran bahasa Inggris. Selain kuesioner, wawancara juga dilakukan terhadap siswa, dan pengajar terkait penilaian mereka terhadap media audio yang telah digunakan.

\section{HASIL DAN PEMBAHASAN}

Bagian ini disusun untuk menjawab tujuan penelitian yaitu mengetahui tingkat kelayakan atau efektivitas model media audio DEC ditinjau dari sisi materi dan media serta menyajikan kelebihan dan kekurangannya.

Gambar 1 berikut mendeskripsikan tingkat kelayakan/efektivitas model media audio DEC dari sisi calon pengguna (siswa).

\section{Efektivitas Model Media Audio DEC}

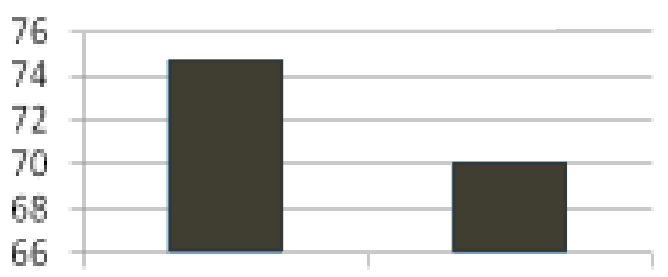

Aspek Materi Aspek Media

Gambar 1. Efektivitas DEC dari Aspek Materi dan Media

Berdasarkan hasil pengolahan data hasil kuesioner mengenai tingkat kelayakan/ efektivitas media audio DEC ditinjau dari aspek materi yang meliputi pengembangan kemampuan berbicara, kemampuan mendengarkan, cakupan materi, penyajian, tingkat kesulitan materi, dan penggunaan bahasa, tingkat efektivitasnya menunjukkan persentase sebesar $74,7 \%$. Sedangkan ditinjau dari sisi kemediaan yang mencakup aspek tempo/kecepatan ucapan, kejelasan suara, kemenarikan suara, tune program, penggunaan efek suara, ilustrasi musik, durasi, dan kemudahan penggunaan, tingkat efektivitasnya menunjukkan persentase sebesar $70,1 \%$.

Sementara itu, menurut pendapat praktisi pendidikan (pendidik/guru) secara umum, DEC merupakan media audio yang sangat baik, terutama untuk meningkatkan kemampuan menyimak dan berbicara. Media audio ini diyakini sangat bermanfaat dalam mendukung pembelajaran bahasa Inggris siswa-siswa di Indonesia. Hal Ini berarti, secara umum model media audio DEC yang dikembangkan telah memenuhi syarat untuk digunakan sebagai bahan ajar dalam pembelajaran bahasa Inggris. Hal ini sejalan dengan prinsip media pembelajaran yang baik dengan beberapa kriteria yang antara lain: mempertimbangkan calon pengguna, kebenaran materi, adanya kejelasan isi materi, adanya tujuan pengembangan media yang spesifik, dan adanya kejelasan dalam konteks seperti apa 
media tersebut digunakan (Roger, 2012: 6-9).

Menurut sebuah penelitian, evaluasi kualitas sumber belajar memegang peranan penting dalam mendesain dan mengembangkan konten pembelajaran yang menarik dan baik. Ada empat kriteria yang digunakan sebagai acuan yaitu kualitas akademik, kualitas pedagogik, kualitas didaktik, dan kualitas teknik. Kualitas akademik menyangkut apakah informasi atau materi yang dikembangkan dapat dipercaya dan akurat. Kualitas pedagogik ditentukan oleh kualitas penyajian materi yang sederhana, adanya interaktivitas yang sesuai, adanya penjelasan yang memadai, adanya tujuan pembelajaran secara jelas, dan adanya latihan untuk penilaian atau assessment. Sementara itu, kualitas dikdaktik menyangkut pada aktivitas belajar dan konten pembelajaran yang tepat; sedangkan aspek kualitas teknis lebih menyangkut pada desain tampilan media (Mhouti, 2013: 30-32).

Hal ini sejalan dengan penelitian senada yang mengungkapkan bahwa materi pembelajaran yang efektif hendaknya memenuhi beberapa persyaratan yang antara lain: memenuhi tujuan pembelajaran yang ditetapkan, akurat, relevan, dan kekinian atau up to date, koheren, tingkat kesulitan dan penggunaan vocabulary/kosa kata yang tepat, penyajian tampilan yang menarik, konsep sederhana dengan tema yang variatif, pengembangan kemampuan bukan hanya pada level mengingat namun juga berpikir, berorientasi pada aplikasi atau penerapan dalam dunia nyata (real world), dan dapat dimanfaatkan sebagai materi pendukung dalam pembelajaran (Carraway, 2008: 11).

Dengan demikian, secara umum media audio DEC telah memenuhi kriteria standar kelayakan yang dikategorikan dalam 2 aspek utama yaitu aspek isi/materi yang menyangkut aspek edukatif dan aspek media yang menyangkut aspek kemenarikan dan teknis dengan persentase di atas 70\% (kategori baik). Pembahasan berikut akan menguraikan lebih rinci hasil evaluasi model media audio DEC untuk aspek isi/materi dan aspek media yang mengarah pada hal-hal yang bersifat teknis estetis.

\section{Evaluasi DEC dari Aspek Isi/Materi}

Gambar 2 berikut menyajikan persebaran butir pertanyaan mengenai efektivitas model media audio DEC ditinjau dari sisi isi/materi. Bila dirunut dari butir-butirnya, terlihat bahwa grafik tertinggi berada pada tingkat pengembangan kemampuan menyimak atau listening dengan persentase tingkat kelayakan sebesar $88 \%$ yang diikuti dengan peningkatan kemampuan berbicara atau speaking dengan persentase sebesar $83 \%$. Ini berarti media audio DEC tepat digunakan sebagai media untuk meningkatkan kemampuan menyimak dan berbicara untuk pembelajar bahasa Inggris. Ini sejalan dengan hasil observasi/pengamatan di mana pada awal pemutaran media, banyak responden yang tidak bisa menangkap isi percakapan, apalagi mempraktikkan berbicara dengan menggunakan ungkapanungkapan yang ada pada percakapan tersebut. Namun, seiring dengan adanya intervensi pembelajaran dengan memanfaatkan media audio DEC ini, kemampuan menyimak dan mendengarkan siswa pun meningkat.

\section{Efektivitas Media Audio DEC dari Aspek Isi/Materi}

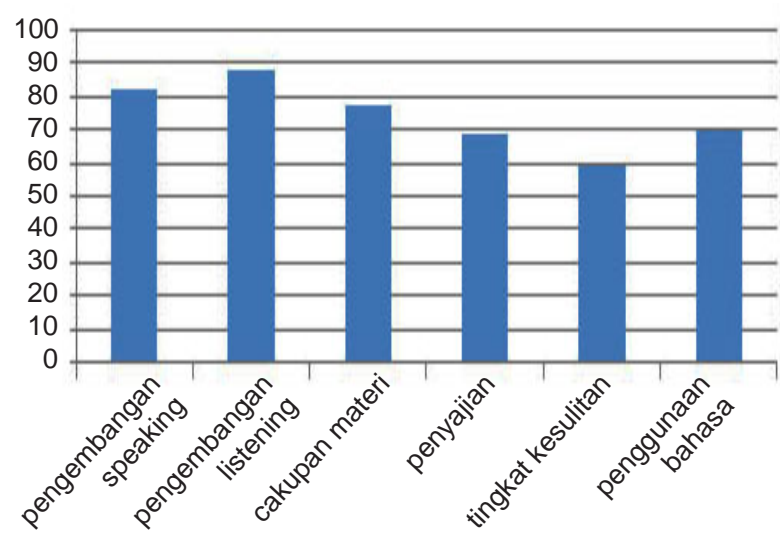

Gambar 2. Butir Pertanyaan dari Aspek Isi/Materi

Media audio DEC memberikan modeling yang tepat bagaimana mengucapkan bahasa Inggris yang lazim digunakan dalam kehidupan sehari-hari. Setelah siswa menyimak media audio DEC setidaknya sebanyak 3 kali, siswa mulai memahami isi materi yang diperdengarkan, bahkan menirukan perintah-perintah narator untuk mengucapkan ungkapan-ungkapan yang 
lazim digunakan dalam percakapan tersebut.

Dengan demikian, saat diminta untuk secara berpasangan melakukan percakapan dalam bahasa Inggris, siswa dapat menggunakan contoh-contoh ungkapan dari model teks atau modeling text yang diperdengarkan. Menurut hasil wawancara dengan pengajar, pola penyajian media audio yang terdiri dari pembukaan, model teks, penjelasan ungkapan, contoh, dan drilling sangat sesuai dengan pola pembelajaran bahasa.

Hasil evaluasi menyangkut aspek materi tersebut sejalan dengan hasil penelitian yang dilakukan terhadap sekelompok pelajar setingkat SMA di Iran dalam penggunaan media audio untuk meningkatkan kemampuan listening. Dari hasil penelitian dinyatakan bahwa kemampuan listening siswa meningkat secara signifikan dengan adanya pemanfaatan media audio yang menggunakan native speaker atau penutur asli sebagai pengisi suaranya (Mohamaskhani, 2013: 132). Hal ini relevan dengan media audio DEC yang juga menggunakan native speaker atau penutur asli dalam memberikan modelling percakapan bahasa Inggris sesuai dengan konteks kehidupan sehari-hari sebagaimana yang telah diungkapkan pada data sebelumnya.

Penelitian senada juga pernah dilakukan pada mahasiswa semester 1 jurusan Pendidikan Bahasa Inggris (PBI) Universitas Negeri Yogyakarta (UNY), dan hasilnya menunjukkan bahwa pemberian input materi listening secara intensif berpengaruh terhadap kemampuan speaking mahasiwa. Pada awalnya, para mahasiswa tersebut mengalami beberapa kesulitan untuk menangkap isi materi listening karena mengalami kesulitan dalam membedakan pengucapan dalam bahasa Inggris, terutama untuk kata-kata yang terdengar mirip. Selain itu, mereka juga belum terbiasa menghadapi aktivitas-aktivitas dalam listening tasks sehingga listening comprehension atau pemahaman mereka pun masih rendah. Namun, seiring dengan pembelajaran listening yang lebih intensif dengan menerapkan strategi pre listening activities (aktivitas sebelum pembelajaran listening), kemampuan listening mahasiswa pun meningkat. Peningkatan kemampuan listening ini berpengaruh pada peningkatan kemampuan speaking mahasiswa jurusan PBI UNY tersebut (Floriasti, 2013: 373-374).

Dengan demikian, media audio DEC yang didesain untuk meningkatkan kemampuan listening dan speaking relevan dengan beberapa hasil penelitian yang ada sebelumnya.

Pada gambar 2, diketahui juga bahwa persentase terendah ditinjau dari sisi materi jatuh pada tingkat kesulitan materi yang hanya mencapai $60 \%$ diikuti dengan penyajian materi dengan persentase sebesar $69 \%$. Berdasarkan hasil wawancara dengan siswa dan pengajar, tingkat kesulitan materi relatif cukup tinggi karena dialog yang cukup panjang padahal tingkat kemampuan menyimak teks bahasa Inggris siswa terbatas. Selain itu, tidak adanya penjelasan situasi percakapan membuat pendengar kesulitan untuk mendapatkan gambaran tentang konteks percakapan tersebut.

Selanjutnya berkaitan dengan kemudahan penggunaan bahasa, terlihat bahwa tingkat persentase menunjukkan angka $70 \%$. Menurut hasil wawancara dengan pengajar dan siswa, penggunaan bahasa hendaknya lebih mudah dipahami. Pembahasan sebaiknya lebih berisi deskripsi tentang ungkapan, bukan penjelasan panjang sehingga mudah dipahami dan diingat oleh pendengar/pembelajar. Sementara itu, cakupan materi menunjukkan persentase sebesar 78\%. Berdasarkan hasil wawancara berkaitan dengan cakupan materi, contoh ungkapan sebaiknya disajikan secara berkelompok sesuai dengn jenis ungkapan dan diberikan pula contoh ungkapan yang lain di luar yang digunakan pada dialog. Demikian juga contoh ungkapan pada bagian drilling sebaiknya disajikan secara berpasangan agar pendengar mendapat gambaran menyeluruh tentang penggunaan ungkapan tersebut.

Dengan demikian, yang harus diperhatikan dalam pengembangan model media audio bahasa Inggris berikutnya adalah menurunkan tingkat kesulitan materi pada level pembelajaran bahasa Ingggris tingkat dasar dan menyesuaikannya dengan 
kurikulum yang berlaku di sekolah. Penyajian materi haruslah lebih memperhatikan siapa yang menjadi target sasaran pengguna, perlunya ada aktivitas atau pemberian task/ latihan sebagai sarana evaluasi untuk mengecek tingkat pemahamanan siswa dan mengaktifkan siswa dalam belajar, serta penggunaan bahasa dan kosa kata yang lebih dekat dengan kehidupan siswa.

\section{Evaluasi DEC dari Aspek Media}

Gambar 3 berikut menyajikan persebaran butir pertanyaan mengenai efektivitas model media audio DEC ditinjau dari sisi media. Bila dirunut dari butir-butir pertanyaan yang diberikan, terlihat bahwa persentase tingkat kelayakan terbesar ditunjukkan pada pemilihan durasi audio yang menunjukkan persentase kelayakan sebesar $81 \%$. Menurut pendapat responden, durasi pembelajaran audio selama 5 menit cukup efektif dalam menjaga konsentrasi pembelajar untuk menyerap materi pembelajaran audio yang disampaikan. Durasi yang relatif pendek ini sangat sesuai dengan rentang perhatian pendengar. Persentase terbesar berikutnya adalah dari sisi kemenarikan suara sebesar $80 \%$ dan kejelasan suara sebesar $76 \%$.

Menurut hasil wawancara, penggunaan suara penutur asli atau native speaker dalam pembelajaran bahasa Inggris pada awalnya memang menyulitkan karena siswa tidak terbiasa mendengar bagaimana native speaker berbicara. Namun, setelah beberapa kali mendengarkan, diberikan motivasi, siswa mulai terbiasa dan dapat memahaminya. Akan tetapi, menurut pendapat responden, lebih baik jika karakter suara yang ditampilkan disesuaikan dengan tingkat usia, misalnya jika karakter yang ditampilkan adalah suara anak seusia SMP, perlu dipilih pengisi suara anak seusia SMP, bukan karakter suara dewasa. Dalam pengucapan pun, tempo atau kecepatan pengucapannya perlu diperlambat di mana persentase kelayakan tempo baru menduduki persentase sebesar $68 \%$.

Selanjutnya ditinjau dari sisi tune program, tingkat efektivitasnya menunjukkan persentase sebesar $74 \%$, sedangkan ilustrasi musik menunjukkan persentase $69 \%$ dan efek suara $67 \%$. Tune program pada dasarnya sudah baik dan singkat, dan narasi lagu yang berbunyi: Make your conversation, easy, joyful, and so happy. Daily English Conversation menggambarkan sebuah motivasi untuk mempelajari percakapan bahasa Inggris dengan mudah dan menyenangkan. Berbeda dengan penggunaan tune program yang sudah dianggap baik, untuk ilustrasi musik, responden lebih menginginkan musik yang bernuansa lebih energik dan riang. Persentase terendah justru ditunjukkan pada penggunaan efek suara untuk memberi ilustrasi suasana di mana percakapan tersebut dilangsungkan. Tingkat kelayakan yang masih rendah ini disebabkan karena menurut pendapat responden, beberapa efek suara yang disajikan justru mengganggu. Oleh karena itu, untuk menggambarkan setting tempat atau suasana, efek suara hanya keras di bagian awal saja, sebelum dialog dimulai lalu melemah pada bagian dialog agar tidak mengganggu konsentrasi percakapan.

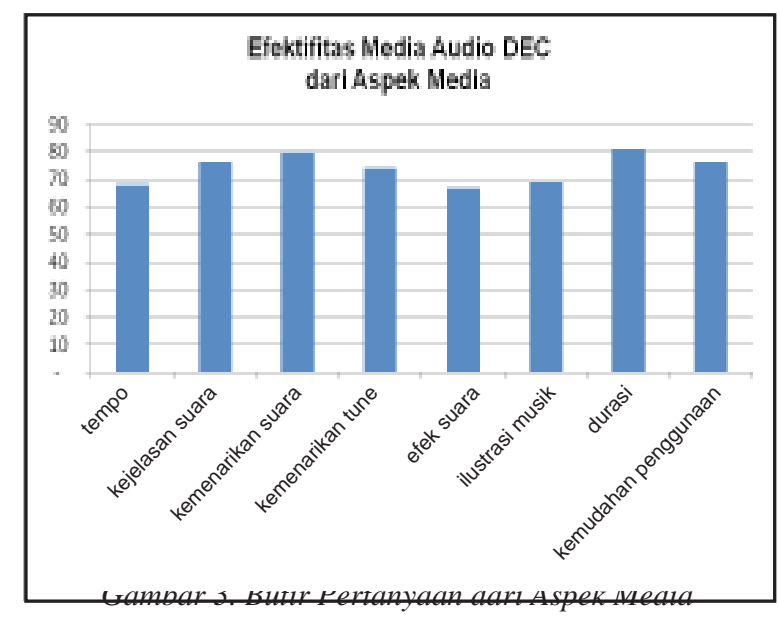

Dalam sebuah penelitian, diungkapkan bahwa tidak ada pedoman yang pasti menyangkut durasi/lama sebuah program audio. Menurut pendapat sebagian responden, durasi yang ideal adalah sepanjang sebuah lagu. Sebagian yang lain berpendapat bahwa durasi sekitar 10 menit atau 15 menit adalah durasi yang ideal. Namun durasi yang melebihi 15 menit dirasa kurang tepat atau terlalu lama untuk sebuah program audio pembelajaran (Taylor dan Clark, 
2010:393). Dengan demikian, program DEC dengan durasi sekitar 5 menit cukup ideal untuk digunakan sebagai sebuah program pembelajaran. Namun pada dasarnya kecukupan durasi sebuah program audio sangat dipengaruhi oleh sasaran pengguna, jenis program, sajian program, dan berbagai pertimbangan teknis lain.

Aspek kemediaan lain yang relevan adalah menyangkut suara. Menurut sebuah penelitian, responden berpendapat bahwa rekaman suara dengan kualitas suara pemain yang bagus lebih dipilih, misalnya rekaman serangkaian program audio yang disajikan oleh penyiar/ presenter yang professional lebih dipilih daripada seorang dosen/guru dengan kualitas suara yang kurang baik (Taylor dan Clark, 2010:392). Jadi, kualitas suara atau kemenarikan suara merupakan hal penting yang harus diperhatikan dari segi teknis estetis kemediaan yang sedikit banyak berpengaruh pada ketertarikan pendengar untuk menyimak program-program pembelajaran yang disajikan. Namun kebenaran materi tetaplah menjadi hal utama. Jadi pada saat perekaman suara pun, pendampingan oleh ahli materi untuk mengantisipasi kesalahan materi saat rekaman sangat diperlukan. Dalam konteks ini, pengisi suara media audio bahasa Inggris DEC yang dipilih adalah sekaligus ahli bahasa (native speakers) sehingga kemungkinan salah dalam pengucapan relatif kecil. Selain itu, karena DEC ini didesain untuk kepentingan belajar, kecepatan/tempo pengucapan juga diperlambat agar lebih berterimakan dan materi yang disajikan lebih mudah dipahami.

Menurut penelitian lain dinyatakan bahwa penggunaan musik yang menyenangkan dan tepat memberi pengaruh positif pada kualitas pembelajaran. Penggunaan musik penting bagi perkembangan bahasa, literasi, kecerdasan, kreativitas, koordinasi, disiplin diri dan relaksasi (Hallam, 2010: 269). Jadi, baik penggunaan musik maupun efek suara berpengaruh pada kemenarikan sebuah program audio. Dalam konteks ini penggunaan musik dan efek suara pada media audio DEC masih perlu diperbaiki agar lebih memberikan atmosfir yang tepat dalam mendukung suasana.

Analisis Kelebihan dan Kekurangan Model

\section{Media Audio DEC}

Media yang baik adalah media yang dapat membantu guru dan siswa untuk mengikuti proses pembelajaran dalam rangka mencapai tujuan pembelajaran yang telah ditetapkan. Demikian juga dengan DEC, sebuah model media audio pembelajaran bahasa Inggris, yang didesain khusus untuk menjawab kebutuhan pembelajar dalam membantu meningkatkan kemampuan berbahasa Inggris, khususnya keterampilan menyimak dan berbicara. Model ini memiliki kelebihan dibandingkan model-model pembelajaran audio bahasa Inggris yang berkembang di lapangan, karena secara umum proses pengembangan DEC telah melibatkan berbagai pihak terkait. Secara umum, proses pengembangan DEC telah melibatkan ahli bahasa yaitu native speaker (penutur asli bahasa Inggris), praktisi lapangan dan ahli materi (guru dan dosen bahasa Inggris), dan pengembang media dari BPMRPK sejak awal pengembangan, proses penulisan, hingga proses produksi sehingga secara kualitas terjaga dengan baik.

DEC merupakan salah satu referensi sumber pembelajaran bahasa Inggris yang berkualitas dengan penyajian materi berupa input text, yaitu teks lisan yang dikemas dalam format dialog yang menyajikan keterampilan berbahasa tertentu (language function) yang biasanya dipergunakan dalam kehidupan sehari-hari. Pada dasarnya media audio ini dapat dimanfaatkan guru sebagai modelling of the text atau contoh teks yang akan dipelajari. Pada tahap ini, siswa mendengar dan merespon berbagai macam teks dengan tujuan komunikasi yang sama. Pemberian sebuah model teks penting karena menjadi acuan bagi siswa dalam mencapai target atau tujuan pembelajaran yang diinginkan. Dengan demikian, mereka mempunyai konsep yang jelas mengenai tujuan yang ingin dicapai dengan membandingkan karya mereka dengan model yang telah diberikan.

Namun demikian, pengembangan model media audio DEC tersebut belum sepenuhnya merujuk pada kurikulum pembelajaran bahasa Inggris yang berlaku di sekolah. Dengan demikian, pada pengembangan model media audio pembelajaran bahasa Inggris di masa 
mendatang, hal tersebut perlu dipertimbangkan. Selain itu, DEC tidak dilengkapi dengan bahan penyerta berupa panduan pemanfaatan untuk guru sehingga kurang maksimal dalam pemanfaatannya. Berbagai kekurangan lain, khususnya terkait dengan hal-hal teknis perlu juga mendapat perhatian dalam pengembangan model media audio pembelajaran bahasa Inggris berikutnya.

\section{SIMPULAN DAN SARAN}

Tingkat kelayakan model media audio DEC dari sisi konten/materi dalam kategori baik. Model media audio ini layak digunakan sebagai media alternatif untuk pembelajaran bahasa Inggris, khususnya untuk meningkatkan kemampuan menyimak dan berbicara dalam bahasa Inggris. Media audio yang dikembangkan ini tepat untuk menjawab tantangan penyediaan sumber belajar bahasa Inggris khususnya untuk meningkatkan kemampuan menyimak dan berbicara.

Model media audio DEC ini sangat baik sebagai model teks pembelajaran berbasis audio yang dapat dipertanggungjawabkan sisi kebenarannya, terutama dari segi isi/materi. Namun, tingkat kesulitan dan materi yang disajikan masih relatif tinggi untuk kalangan pembelajar setingkat SMP. Hal ini menyangkut tingkat penggunaan teks dialog yang relatif masih panjang padahal tingkat kemampuan menyimak dan berbicara pembelajar masih terbatas. Selain itu, teks dialog yang ditampilkan belum disertai dengan penjelasan situasi percakapan sehingga membuat pendengar kesulitan untuk menangkap konteks pembicaraan.

Tingkat kelayakan model media audio DEC dari sisi media khususnya menyangkut aspek teknis dan estetis dalam katagori baik. Durasi program DEC yang berkisar 5 menit untuk tiap programnya dianggap sesuai dengan rentang daya perhatian dan konsentrasi pendengar dalam menyimak materi pembelajaran berbasis audio. Namun untuk hal teknis estetis yang menyangkut penggunaan efek suara, ilustrasi musik, dan kecepatan pengucapan perlu diperbaiki sehingga media audio yang disajikan menjadi lebih baik dan menarik.

Model media audio DEC merupakan model audio pembelajaran bahasa Inggris yang secara kualitas unggul karena telah melibatkan berbagai komponen, baik ahli bahasa, ahli materi, ahli media, maupun praktisi lapangan dalam proses pengembangannnya. Media audio ini sangat baik untuk dijadikan sebagai input text dalam tahap modelling of the text (pemberian contoh teks yang akan dipelajari) dalam proses pembelajaran bahasa Inggris. Meskipun demikian, ada beberapa hal yang perlu diperbaiki terutama menyangkut pengembangan materi dan hal-hal yang berkaitan dengan teknis estetis pada pengembangan model media audio bahasa Inggris berikutnya.

Berkaitan dengan tingkat kesulitan materi dan penyajian materi, perlu ditata ulang dan disesuaikan dengan level kemampuan berbahasa Inggris siswa yang sebagian besar berada pada level dasar atau elementary. Pemetaan materi perlu dilakukan secara cermat dengan mempertimbangkan tujuan pembelajaran yang telah ditetapkan dan tingkat kemampuan pendengar. Penyajian program juga perlu diperbaiki dengan memberikan penjelasan oleh narator mengenai konteks percakapan yang disajikan.

Kemudian pengemasan program, khususnya penggunaan ilustrasi musik dan efek suara perlu dikerjakan dengan lebih baik sehinga bisa lebih menghidupkan suasana, bukan justru mengganggu konsentrasi karena suasana yang dibangun kurang tepat. Mengingat level kemampuan berbahasa Inggris pembelajar masih rendah, maka tempo pengucapan dialog oleh native speaker juga perlu diperlambat, di bawah pembicaraan dalam bahasa Inggris secara normal.

\section{PUSTAKA ACUAN}

\section{Buku}

Sukmadinata, Nana Syaodih. 2005. Metode Penelitian Pendidikan.Bandung: PT remaja Rosdakarya.

Wang, Victor C.X. 2010. Assessing and Evaluating Adult Learning in Career and Technical Evaluation. Hangzhou: Zhejiang University Press. 


\section{Jurnal/Prosiding/Disertasi/Thesis/Skripsi}

Adi, Sugeng Susilo. 2016. The Development of English Language Learning Instruments Using Audio-Based Media. IOSR Journal of Research \& Method in Education (IOSRJRME), Volume 6, Issue 2 Ver. III (Mar. - Apr. 2016), halaman 01-12.

Adnan, Aryuliva. 2012. Pengajaran Menyimak Bahasa Inggris: Masalah dan Solusinya. Lingua Didaktika: Jurnal Bahasa dan Pembelajaran Bahasa,Universitas Negeri Padang Volume 6 No 1, Desember 2012 halaman 1-9.

Astuti, A.E, Sunardi, dan Nurkamto, Joko. 2014. Pengaruh Metode Pembelajaran Role Play dan Story Telling Berbantuan Video terhadap Keterampilan Berbicara Bahasa Inggris Ditinjau dari Motivasi Belajar. Jurnal Teknologi Pendidikan dan Pembelajaran. Vol.2 No.3 Mei 2014.

Floriasti, Tri Wahyuni. 2013. Improving Speaking Skills through the Use of Integrated Listening and Speaking Material for Student Teachers Academic Year 2012/2013 p 369-376. Conference Proceedings, Bangkok: $3^{\text {rd }}$ International Conference on Foreign Language Learning and Teaching, March 1516, 2013, Language Institute of Thammasat University (LITU), Thailand. Tersedia di: http:/ /www.litu.tu.ac.th/journal/FLLTCP/Proceeding/ 369.pdf (diunduh 10 November 2013).

Hallam, Susan. 2010. The power of Music: Its Impact on the Intellectual, Social and Personal Development of Children and Young People, pages 269-289 Tersedia di: http:// journals.sagepub.com/doi/abs/10.1177/ 0255761410370658 (diunduh 10 November 2017).

Mhouti, A.E.dkk. 2013. How to Evaluate the Quality of Digital Learning Resources. International Journal of Computer Science Research and Application, 2013, Vol. 03, Issue. 03, pp. 2736.

Mohamadkhani, Kamran. 2013. The Effect of Using Audio Files on Improving Listening Comprehension. International Journal of Learning \& Development, 2013, Vol. 3, No. 1. p 132-137.

Suparti. 2016. Evaluasi Model Media Audio Permata Nusantara untuk Pendidikan Anak Usia Dini (PAUD). Jurnal Teknodik Vol. 20 Nomor 1, Juni 2016.

Sayuri. 2017. English Speaking Problems of EFL Learners of Mulawarman University. Indonesian Journal of EFL and Linguistics Vol. 1 No. 1, 2016.
Taylor, Lucy dan Clark, Steve. 2010. Educational Design of Short, Audio-Only Podcasts: the Teacher and Student Experience. Australasian Journal of Educational Technology Vol 26, No 3. 2010. p 386-399

\section{Lain-lain}

Ardianingsih, Lidwina Sri dan Juhana. 2013. Evaluasi Kualitas Bahan Ajar Jarak Jauh pada Bahan Ajar PBIS4101/ Listening I (Tahun II). Laporan Penelitian Hibah Bersaing. Tangerang: Universitas Terbuka.

Alzuhdy, Yosa A. 2014. Meningkatkan Keterampilan Listening Lewat.

Sumber-sumber Belajar . Tersedia di: http:// staff.uny.ac.id/sites/default/files/pengabdian/ yosa-abduh-alzuhdy-ss-mhum/artikel-ppmbelajar-listening-lewat-online.pdf (diunduh 1 Agustus 2017).

Carraway, C. dkk. 2008. Priorities for Evaluating. Instructional Materials: Research Update. Florida: Florida Departement of Education Bureau of Curriculum and Instruction Office of Instructional Materials.

Citra, Shelvy Dwi. 2016. Ini Hasil Survei EF Soal Skill Berbahasa Inggris Masyarakat Indonesia. Tersedia di: http://marketplus.co.id/2016/05/ ini-hasil-survei-ef-soal-skill-berbahasa-inggrismasyarakat-indonesia/ (diunduh 1 Agustus 2017).

Forest, Ed. 2014. ADDIE Model: Instructional Design. Terrsedia di: https:// educationaltechnology.net/the-addie-modelinstructional-design/ (diunduh 8 Agustus 2017).

Mulyati, Yeti. 2015. Modul 1. Hakikat Keterampilan Berbahasa. Tersedia di: www.pustaka.ut.ac.id/ lib/wp-content/.../pdfmk/PDGK4101-M1.pdf (diunduh 10 Agustus 2017).

Nurkamto, Joko. 2003. Problema Pengajaran Bahasa Inggris di Indonesia. Tersedia di: http:/ /linguistik-indonesia.org/images/files/ ProblemPengajaranBahasalnggrisdilndonesia.pdf (diunduh 9 Agustus 2017).

Rahadi, Aristo. 2016. Evaluasi Pengembangan dan Pemanfaatan Media. Yogyakarta: Bahan Pelatihan Penyusunan Instrumen Pengembangan Model Media Audio Pembelajaran tanggal 13 April 2015 di hotel Sahid Raya, Yogyakarta.

Risa, S. 2015. Hubungan antara Keterampilan Menyimak Informasi melalui Media Audio Visual dan Keterampilan Berbicara Siswa Kelas X Sekolah Menengah Kejuruan Kesehatan Widya Tanjungpinang Tahun Pelajaran 2014/2015. Tanjungpinang: 
Fakultas Kepengajaran dan IImu Pendidikan, Universitas Maritim Raja Ali Haji Tanjungpinang.

Rogers, Fred. 2012. A Framework for Quality in Digital Media for Young Children. Tersedia di: http://cmhd.northwestern.edu/wp-content/ uploads/2015/10/Framework_Statement_2April_2012-Full_Doc-Exec_Summary-1.pdf (diunduh 3 November 2017).

Susanti, Mariana, 2017. Sesjen Kemdikbud: Tingkatkan Peran Lembaga dan Sinergi Organisasi. Tersedia di: http:// radioedukasi.kemdikbud.go.id/read/1552/ sesjen-kemdikbud-tingkatkan-peranlembaga-dan-sinergi-organisasi.html (diunduh 11 Agustus 2017).

\section{Ucapan Terima Kasih}

Penulis menyadari bahwa artikel ini dapat diselesaikan atas dukungan dan bantuan dari berbagai pihak. Oleh karena itu, penulis mengucapkan terima kasih kepada semua pihak yang telah memberikan kontribusi dalam penyelesaian artikel ini. Secara khusus, ucapan terima kasih penulis sampaikan kepada Drs. Bambang Warsita, M.Pd dan Dr. Oos M. Anwas sebagai dewan redaksi jurnal Teknodik atas koreksi dan masukannya. 